\title{
The Antecedents of Interactive Loyalty
}

\section{Anthony Palomba, University of Florida, USA}

\begin{abstract}
Brand loyalty towards video game consoles may have several antecedents. Gender, genre of video games and network externality may impact brand loyalty, mediated by perceptions of video game console brand personalities. This study investigated these relationships by conducting a principal component factor analysis and testing a structural equation model. The seventh generation of video game consoles was selected as the focal concept. The video game consoles examined included Nintendo's Wii, Microsoft's XBOX 360 and Sony's PlayStation 3. The findings suggest that consumers perceive all video game consoles as competent in nature, and that genre has a tremendous impact upon brand loyalty, perceptions of brand personality as well as network externality. For brand managers and industry practitioners, this study provides demonstrates which variables may influence how consumers create brand personalities of video game consoles and cultivate loyalty toward them. This also furthers and introduces the concept of brand relationship theory into the video game industry.
\end{abstract}

Keywords: video games, brand management, brand loyalty 


\section{Introduction}

As consumers interact and engage video game consoles, which may be defined as stationary video game devices that rely on a connection to a television screen, they may cultivate a relationship with them, and realize certain brand personality traits from them. It has been found that consumers possess individual as well as aggregate video game console brand personality perceptions, which are defined as the consumers' commonly perceived brand personality traits across all seventh generation video game consoles (Palomba, 2014). This study is interested in exploring the latter concept further, by examining the antecedents of aggregate video game console brand personality perceptions such as gender, how often consumers play video games socially or alone (network externality), as well as consumers proclivities toward certain video game genres (See Figure 1). Additionally, this study posits that the aggregate seventh generation video game console brand personality perceptions influence aggregate seventh generation video game console brand loyalty.

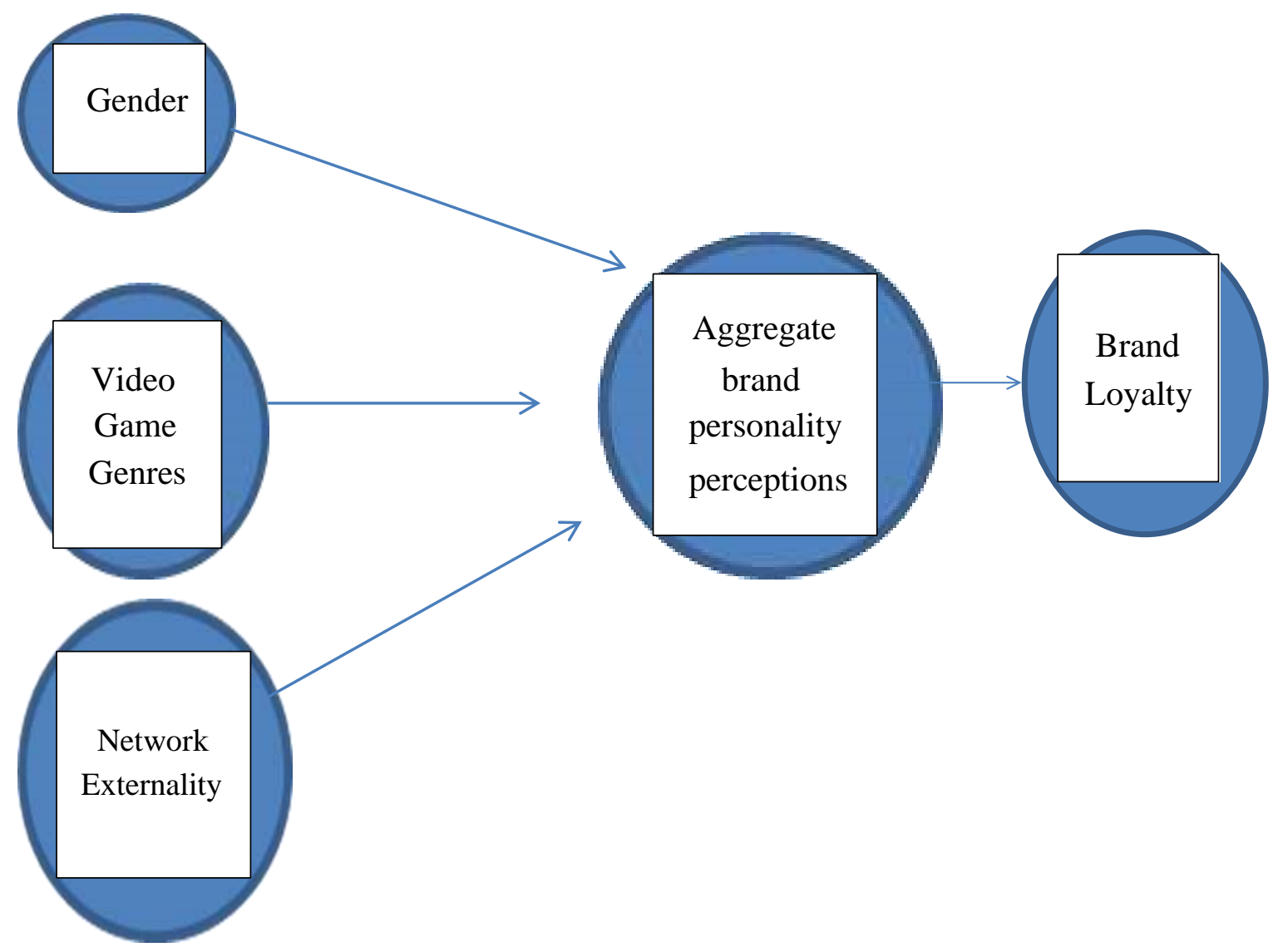

Figure 1. Structural Equation Model 
Previous studies have not explored aggregate video game console brand personality perceptions. Brand personality perceptions behind television channels and newspapers have been examined, demonstrating that consumers can maintain brand relationships and brand personality perceptions with media products (Chan-Olmsted \& Cha, 2007; Kim, Baek, \& Martin, 2010). Moreover, video game brand loyalty is impacted by consumer experience with as well as attitudes toward video game brands (Kwak, McDaniel, \& Kim, 2012). These symbolic and emotional connections with video game console brands can influence video game console brand personality perceptions as well as consumer loyalty toward video game console brands (Freeman, 2004). Consumers distinctly perceive brand personality traits in each seventh generation video game console, as well as aggregate video game console brand personality traits across all seventh generation video game consoles (Palomba, 2014). Lin (2010) found that video game consumers who were extroverted were likely to be drawn to excitement, competence and sincerity brand personalities in video games and toys. However, in this study, BANDAI brand hand-held video games were used, not video game consoles. Lastly, there are mixed findings regarding whether or not females are more brand conscious than males (Fournier, 1998; Guest, 1964; Nair \& Mohandas, 2012).

The seventh generation of video game consoles includes Nintendo's Wii, Microsoft's Xbox 360 and Sony's PlayStation 3 (PS3) (Benedetti, 2012; Chen \& Streitfeld, 2013; Smith, 2012). The Wii was introduced in 2006, the Xbox 360 was introduced in 2005 and the PS3 was introduced in 2006 (“ABC News," 2005; Morris, 2006; Schiesel, 2006). Since the Wii U was introduced in 2012, commencing the start of the eighth generation of video game consoles, consumers had roughly seven years to become familiar with the seventh generation video game consoles as the latest in video game technology (Wingfield, 2012). As Nintendo, Microsoft and Sony have all introduced new eighth generation video game consoles into the marketplace (Wii U, Xbox One and PlayStation 4, respectively), this creates an opportunity to study which variables impact the aggregate seventh generation video game console brand personality perceptions as well as how they may influence aggregate seventh generation video game console brand loyalty. Consumers are more likely to have played or engaged with seventh generation video game consoles during their seven-year tenure, and therefore are likely to have figured out their video game console brand loyalties and brand personality perceptions. 
This study will advance the academic literature on video game brand marketing as well as how impactful consumer video game console brand personality perceptions are toward video game console brand loyalty. For the industry, it will aid practitioners in understanding what may impact aggregate brand personality perceptions of future generations of video game consoles. Media managers will be able to use this model to test how aggregate video game console brand personality perceptions are formulated and maintained by consumers. This may allow them to measure the aggregate video game console industry's brand personality perceptions, and compare it against their own video game console's brand personality perceptions. Moreover, this type of model will allow industry managers to measure how video game genre popularity, consumers' propensity to play video games with others or alone, and consumers' gender reinforce or alter video game consoles' brand personality perceptions. Based on this model, media managers may use advertisements to inform consumers as to how to engage with or perceive a video game console's brand personality traits, as well as what video game genres should be associated with a video game console.

\section{Literature Review}

Today, video game consoles have become ubiquitous throughout U.S. households. In fact, roughly $56 \%$ of all households in the United States own at least one seventh generation video game console and $65 \%$ of those video game consoles are located in the living room (Nielsen, 2012). The average video game player is roughly thirty years old, has played video games for over a decade and spent over \$24 billion on video games, hardware and accessories in 2011 ("Entertainment Software Association," 2012b; 2013). Video game play serves as a social activity, as over $60 \%$ of video game players play with their friends in either a physical, fixed space or through online forums ("Entertainment Software Association," 2012b). The video game console marketplace is extraordinarily competitive and intense. In early December of 2013, the Nintendo Wii held a 38.3\% market share (45.03 million Nintendo Wii video game consoles sold), the Microsoft Xbox 360 held a 38.3\% market share (44.96 million Xbox 360 video game consoles sold), and the Sony PlayStation 3 held a 23.4\% market share (27.53 million PlayStation 3 video game consoles sold) ("VGChartz," 2013d). 


\section{Branding \& Brand Relationship Theory}

The existence of brands allows consumers to form relationships and ascribe identities to particular product lines. Consumers cultivate relationships and interests with particular services and products (Fournier, 1998). The theory of brand relationship states that, over time, consumers have a proclivity toward fostering relationships with brands as well as describing them as human relationships (Fournier, 1998). As a result, it is believed that consumers who can outline human relationships with brands may also possess video game console brand loyalty (Tsai, 2011). Internally, video game corporations must be sure to demonstrate new features or points of differentiation between themselves and competitors, but also amongst themselves, as the latest PlayStation 4 should demonstrate tremendous advances in technology and game-playing experiences compared to its predecessor, the PlayStation 3 (Snow, 2012). This strategy allows for unique relationships and loyalty to manifest between consumers and the different video game console lines. Video game console attributes and characteristics contribute to the overall video game playing experience, from which consumers perceive certain human traits.

\section{Brand Loyalty}

Brand loyalty considers the bond between consumers and brands as a unique relationship. According to Oliver (p.34, 1999), brand loyalty is defined as "a deeply held commitment to rebuy or repatronize a preferred product/service consistently in the future, thereby causing repetitive same-brand or same brand set purchasing, despite situational influences and marketing efforts having the potential to cause switching behavior." Specifically, attitudinal brand loyalty includes a degree of tendency toward a distinct significance associated with a brand (Chaudhuri \& Holbrook, 2001). The manner in which brand personalities are perceived may impact attitudinal brand loyalty (Kim, Magnini, \& Singal, 2011). It has been found that loyalty from consumers can be cultivated by the personality features consumers attribute to corporations (Anisimova, 2007). From this, consumers not only may perceive brand relationships with video game consoles, but also video game corporations. Therefore, video game console brand loyalty may create or reinforce video game corporation brand loyalty.

Brand loyalty not only affects the relationship between a consumer and a brand, but it may also be detrimental to rival brands. In fact, consumers who are committed to a particular brand may 
eschew information that runs counter to their beliefs, which may lead them to vilify other rival brands (Ahluwalia, 2000). Still, it is possible to change the perceptions of consumers if they perceive there to be overwhelming evidence to suggest a rival brand has greater service or quality (Jain 2003; Jain \& Maheswaran, 2000; Raju, Rao, \& Montgomery, 2009). Brand loyalty is a logical consequence of the formulation and growth of perceptions of video game console brand personalities. As in human relationships, consumers may be loyal to relationships they invest time and energy into preserving over a particular period of time.

\section{Perceptions of Video Game Console Brand Personalities}

As previously introduced, consumers conceptualize human personality traits to brands (Aaker 1997; Brakus, Schmitt, \& Zarantonello, 2009). Aaker (1997) defines brand personalities as adjectives that are typically ascribed to humans that consumers assign to brands. Aaker's (1997) brand personality scales found that brand personality traits may fall into five main dimensions (scales): (1) sincerity, (2) excitement, (3) competence, (4) sophistication and (5) ruggedness. Using Aaker's (1997) brand personality scales along with other personality traits gleaned from a focus group, one study found that there were aggregate seventh generation video game console brand personality perceptions (Palomba, 2014). Distinctive brand personalities can help cultivate relationships between consumers and brands. Consumers have predilections toward brands that match their perceived self-image (Govers \& Schoormans, 2005; Lin, 2010) and serve as self-symbols or a source of self-expression (Keller, 1993). Perceived product brand personalities have been found to increase consumer loyalty, help differentiate between products as well as coax active reception of information within consumers (Aaker, 1992; Biel, 1992; Fournier, 1998). Consumers have stronger relationships with brands if they exude distinct brand personalities, which may lead to brand loyalty (Doyle, 1990; Fournier, 1998; Harris \& Flemming, 2005; Kim, Magnini, \& Singal, 2011; Kumar, Luthra, \& Datta, 2006). Hence, it is likely that the aggregate seventh generation video game console brand personality perceptions will have an impact on aggregate seventh generation video game console brand loyalty. As consumers engage in video game play with video game consoles, active experiences and memories are witnessed by the consumers. Over time, this may advance into perceived brand relationships, in which consumers perceive particular video game console brand personality traits. If these traits are positive, or if consumers continue to play video game consoles, it is likely that the perceptions will become stronger and more defined from the standpoint of the 
consumers. H1: Aggregate seventh generation video game console brand personality perceptions will have a positive impact on aggregate seventh generation video game console brand loyalty.

\section{Gender}

Predominantly, males invest significant time in playing video games, but this trend is quickly changing. According to a survey by the Entertainment Software Association (2012a), nearly $47 \%$ of video game players are female and $53 \%$ of video game players are male. This has been corroborated by one study that found that females are active and consistent participants in online video game play (Williams, Yee \& Caplan, 2008). The amount of gameplay among females is also influenced by their perception of other females' actual time spent playing video games (Cruea \& Park, 2012). Still, the vast proportion of video games often include elements such as direct competition, role definitions and ostensibly clear goals, which all typically appeal to males (Lucas \& Sherry, 2004), as opposed to females, who habitually prefer more thoughtprovoking video games (Greenberg, Sherry, Lachlan, Lucas, \& Holmstrom, 2008). Since this is a relatively new trend, it remains unknown as to whether or not female perceptions and relationships with video game console brands will be similar to those of males.

Gender may impact aggregate seventh generation video game console brand personality perceptions since males and females play video games differently. There have been inconsistent findings regarding which gender is more brand conscious (Guest, 1964; Fournier, 1998; Levy, 1999; Nair \& Mohandas, 2012). Males are spurred by game challenges and enjoy playing video games in teams more than females (Eglesz, Feteke, Kiss, \& Izzo, 2005). This study also demonstrated that those who play video games more often become more involved and emotionally tied toward them (Eglesz, Feteke, Kiss, \& Izzo, 2005). One study found that females were not as motivated to play video games as males were because the rewards offered, such as accomplishment in completing a level, did not appeal to them (Hamlen, 2010).

RQ1: Does gender influence aggregate seventh generation video game brand personality perceptions? If so, how? 


\section{Video Game Genres}

In consideration of sales and overall popularity, there are prevalent video game genres associated with each seventh generation video game console. Since 1985, The Super Mario Brothers series has been linked to the Nintendo corporate brand (Totilo, 2012). Thus, the platform and action genres typify what Nintendo has traditionally offered to consumers during its tenure in the video game industry. Nintendo has used the Wii to allow consumers to revisit its familiar stable of video game characters such as Donkey Kong or Link. The Wii introduced new elements of interactive video game play by allowing consumers to use their bodies as part of the video game play experience. It has offered these types of motion-control experiences through video game genres such as sports, fitness and racing, which are generally perceived to be for casual video game players, as these video games are less complicated to play and require little instruction or dedication ("Digital Trends Staff," 2012 "VGChartz," 2013b). The Wii brand sports and fitness titles comprise half of the top ten best-selling video games, though three of the top ten best-selling video games are from the Super Mario Brothers series ("VGChartz," 2013b).

The Xbox 360 has been positioned by Microsoft to be the superior video game console in the seventh generation by offering consumers an unparalleled integrated media experience from which they can connect to alternative media options. Additionally, The Xbox 360 has become a highly favored video game console brand among hardcore video game players, or those who seek highly-complex and competitive video game play experiences (Deleon, 2010; "GameSpy Staff," 2009). Thus, the Xbox 360 offers a variety of shooting and action genre video games to appeal to hardcore gamers (Deleon, 2010). Its best-selling video games include the Call of Duty series, which has collectively sold over forty million copies in North America ("VGChartz," 2013c). For the Xbox 360, eight of the top ten best-selling video games are of the shooter genre ("VGChartz," 2013c). Sony has marketed the PlayStation 3 as a video game console that delivers sophisticated storylines and an alternative video game console for integrated media experiences against the Xbox 360. The PlayStation 3's most popular video games include racing and role-playing genres found in the Gran Turismo, Grand Theft Auto as well as Call of Duty series ("VG Chartz," 2013a). These video game series incorporate fantasy, competition and adventure skewed toward an older audience (Nielsen, 2009). Additionally, the top four 
best-selling video games for the PlayStation 3 are all from the shooter-genre based Call of Duty series ("VGChartz," 2013a).

Consumers' predilection toward particular video game genres will affect the aggregate seventh generation video game console brand personality perceptions. Consumers who interact with video game consoles generally access alternate entertainment options such as television or movies through the video game console, or play video games on it. Since certain video game genres are more widely embraced on particular video game consoles than others, it is likely that video game genres can affect how consumers perceive and foster aggregate seventh generation video game console brand personality perceptions.

RQ2: Do video game genres impact the aggregate seventh generation video game console brand personality perceptions? If so, how?

\section{Network Externality}

Network externality may be viewed as how a product or service may accrue value as more consumers purchase or engage it (Katz \& Shapiro, 1985). If many consumers purchase or engage with a particular product, they will contribute to a positive consumption externality, as other consumers will notice that many consumers have purchased or engaged a product and will in turn ascribe perceived product utility. Consumers will be more inclined to play a particular video game console if their fellow peers do so, in turn enhancing the perceived video game console value. Consumers will likely perceive different brand personality traits through different video game play experiences, which may influence whether or not consumers are playing video games with friends or by themselves.

RQ3: Does network externality influence the aggregate seventh generation video game console brand personality perceptions? If so, how?

\section{Data Collection Procedure}

An online survey was pre-tested and then sent out to a convenience sample of students at a southeastern university in the United States. Unless extra credit was offered by faculty, students were told that there would be no incentive provided to them by taking the online survey. A total 
of five hundred and ninety six participants took the survey, and $83 \%$ of the participants completed it. Participants were removed from the data matrix if answers were inconsistent with previous responses, left answer choices blank or completed the survey in under five minutes. The questionnaire consisted of ninety-two items, sixty-three of which were brand personality trait questions. Two-hundred and ninety eight participants remained for data analysis.

\section{Measurements}

In order to measure brand personality perceptions, a brand personality scale that captured the aggregate seventh generation video game console brand personality perceptions was used (Palomba, 2014). This scale was largely structured on Aaker's (1997) brand personality scale. Brand personality questions were structured as "To what degree do the following traits describe the $[\mathrm{X}]$ video game console brand" on a 1-5 Likert scale 1(Not at all descriptive) to 5(Very descriptive). The results demonstrated that, across the seventh generation of video game consoles, consumers perceived brand personality traits such as confident, intelligent, leader, independent and upper-class. This scale was found to have an eigenvalue of $9.24 \%$ and explained $54.32 \%$ of the variance in the data correlation matrix. This brand personality scale's Cronbach alpha score $(\alpha=.89)$ was found to be statistically significant $(\mathrm{p}<.001)$.

To measure brand loyalty, Delgado-Ballester, E.'s, Munuera-Aleman's, \& Yague-Guillen's (2003) brand loyalty scale was used. This scale was selected because it considers overall consumer satisfaction and how strong the relationship is between the brand and consumer, based on studies by Dick and Basu (1994) and Bloemer and Kasper (1995). The items included "I consider myself to be loyal to $[\mathrm{X}]$ video game console," and "If the store was out of $[\mathrm{X}]$ video game console, I would go somewhere else to buy it" and "I recommend to buy [X] video game console." This measurement employed a five point Likert scale from 1 (strongly disagree) to 5 (strongly agree) and its Cronbach alpha score was .73.

To measure video game genres, participants were asked to rate how frequently they played each one. A video game genre list constructed by Phan, Jardina, Hoyle, \& Chaparro, (2012) was used. This construct was comprised of a twelve item list that included "social," "puzzle/card," "music/dance," "strategy," "role playing," "action," "educational," "simulation," "fighting," "sports," "driving," and "adventure." Several video game examples were placed beside each 
genre to help define each genre category for participants. This measurement employed a five point Likert scale from 1 (not frequently) to 5 (very frequently) and its Cronbach alpha score was .85. To measure network externality, a scale from Thornham (2008) was used regarding how consumers felt about playing video games through video game consoles with others as well as if this stimulated interest in purchasing video game consoles. The three items included "I only play when other people are playing," "I mostly game on my own," and "I mostly game with other people." Since this study is exploratory in nature, other self-made questions were also inserted, such as "I enjoy playing video games when others are around," and "When I see that my friends have a video game console, I become more interested in purchasing one for myself." This measurement employed a five point Likert scale from 1 (strongly disagree) to 5 (strongly agree) and its Cronbach alpha score was .59.

\section{Statistical Analysis}

Structural equation modeling was performed using aggregate seventh generation brand personality perceptions as its mediator. Structural equation modeling was selected as a technique since it is used to evaluate whether or not data fit a model comprised of theoretical constructs (Yoon \& Uysal, 2005). Additionally, structural equation modeling executes simultaneous testing of multiple relationships, which helps to reduce the chances of measurement error (Anderson \& Gerbing, 1988).

\section{Results}

As stated, two-hundred ninety-eight participants were analyzed during this study. There were one hundred and eighty two females and one hundred sixteen males. Roughly $68.5 \%$ of participants identified as Caucasian, followed by Latino/Hispanic (16.8\%), Asian (5.4\%), African-American (5.0\%), other (3.4\%) and Pacific Islander (1.0\%). Over half of the participants came from annual household incomes of over $\$ 80,000$. SPSS and SPSS AMOS statistical packages were used in the data analysis.

\section{Data Analysis}

To test for model fit, Bagozzi and Yi (1988) suggest using The Comparative Fit Index (CFI), Normed Fit Index (NFI), and Root Mean Square Error of Approximation (RMSEA) among other tests. The CFI in this model was .401 , which was less than the recommended threshold 
of greater than or equal to .90 (Bentler, 1992). The NFI in this model was .455, which was less than the recommended threshold of greater than or equal to .90 (Bentler, 1992). The RMSEA in this model was .149, which was greater than the recommended threshold of less than or equal to .08 (Hu \& Bentler, 1999). Thus, the structural equation model was found to be not statistically significant, but it did produce statistically significant relationships among certain variables. The first hypothesis examined how the aggregate seventh generation video game console brand personality perceptions impacted aggregate seventh generation video game console brand loyalty. The composite mediator positively impacted brand loyalty $(\beta=.331$, $\mathrm{p}<.002$ ) (see Table 1). Hence, the first hypothesis was supported. The first research question considered if gender impacted the aggregate brand personality perceptions of the seventh generation of video game consoles. This variable did not fit into the structural equation model. A multiple linear regression was performed to test these variables' influence on the mediator, but the results were not statistically significant.

Table 1. Path Analysis Findings for Impact of Network Externality and Genre on Perception of Brand Personalities of Video Game Console Brand Personalities and Video Game Console Brand Personalities Impact on Brand Loyalty in Structural Equation Model

\begin{tabular}{|c|c|c|c|c|c|}
\hline Path & & & Coefficients & S.E. & C.R. \\
\hline $\begin{array}{l}\text { Perceptions of } \\
\text { Brand Personalities }\end{array}$ & $\begin{array}{l}<------ \\
-\end{array}$ & Network Externality & .053 & .017 & 3.076 \\
\hline $\begin{array}{l}\text { Perceptions of } \\
\text { Brand Personalities }\end{array}$ & $\begin{array}{l}<------ \\
- \\
\end{array}$ & Video game genres & $.099 *$ & .075 & 1.326 \\
\hline Brand Loyalty & $\begin{array}{l}<------ \\
-\end{array}$ & $\begin{array}{l}\text { Perceptions of Brand } \\
\text { Personalities }\end{array}$ & $.331 *$ & .061 & 5.408 \\
\hline
\end{tabular}

$* \mathrm{p}<.002$

The second research question examined if video game genres had a positive impact on the aggregate seventh generation video game console brand personality perceptions. Video game genres positively impacted the aggregate seventh generation video game console brand personality perceptions $(\beta=.099, \mathrm{p}<.002)$ (see Table 1).

The third research question investigated if network externality influenced the aggregate seventh generation video game console brand personality perceptions. Network externality did not significantly impact the aggregate seventh generation video game console brand personality perceptions (see Table 1). During this study, a unique finding was made. Video game genres 
positively impacted $(\mathrm{p}<.001)$ each of the individual network externality indicators (see Table 2). Additionally, video game genres positively impacted $(\mathrm{p}<.001)$ all of the aggregate seventh generation video game console brand loyalty indicators, but for the brand loyalty indicators for the Xbox 360 .

Table 2. Path Analysis Findings for Impact of Video Game Genre on Network Externalities and Brand Loyalty in Structural Equation Model

\begin{tabular}{|c|c|c|c|c|c|}
\hline Path & & & Coefficients & S.E. & C.R. \\
\hline $\begin{array}{l}\text { I only play when other } \\
\text { people are playing }\end{array}$ & <-------- & $\begin{array}{l}\text { Video game } \\
\text { genres }\end{array}$ & $3.03 *$ & .069 & 43.98 \\
\hline I mostly game on my own & <-------- & $\begin{array}{l}\text { Video game } \\
\text { genres }\end{array}$ & $2.22 *$ & .070 & 31.65 \\
\hline $\begin{array}{l}\text { I mostly game with other } \\
\text { people }\end{array}$ & <-------- & $\begin{array}{l}\text { Video game } \\
\text { genres }\end{array}$ & $2.92 *$ & .078 & 37.26 \\
\hline $\begin{array}{l}\text { I enjoy playing video games } \\
\text { with others }\end{array}$ & <-------- & $\begin{array}{l}\text { Video game } \\
\text { genres }\end{array}$ & $2.47 *$ & .073 & 33.68 \\
\hline $\begin{array}{l}\text { When I see that my friends } \\
\text { have a video game console, } \\
\text { I become more interested in } \\
\text { purchasing one for myself }\end{array}$ & <-------- & $\begin{array}{l}\text { Video game } \\
\text { genres }\end{array}$ & $3.46^{*}$ & .071 & 48.43 \\
\hline $\begin{array}{l}\text { I consider myself to be loyal } \\
\text { to the Wii video game } \\
\text { console }\end{array}$ & <-------- & $\begin{array}{l}\text { Video game } \\
\text { genres }\end{array}$ & $.795^{*}$ & .23 & 3.47 \\
\hline $\begin{array}{l}\text { I consider myself to be loyal } \\
\text { to the Xbox } 360 \text { video game } \\
\text { console }\end{array}$ & <-------- & $\begin{array}{l}\text { Video game } \\
\text { genres }\end{array}$ & .230 & .36 & 0.65 \\
\hline $\begin{array}{l}\text { I consider myself to be loyal } \\
\text { to the PlayStation } 3 \text { video } \\
\text { game console }\end{array}$ & <-------- & $\begin{array}{l}\text { Video game } \\
\text { genres }\end{array}$ & $1.01 *$ & .22 & 4.53 \\
\hline $\begin{array}{l}\text { I recommend to buy the Wii } \\
\text { video game console }\end{array}$ & <-------- & $\begin{array}{l}\text { Video game } \\
\text { genres }\end{array}$ & $1.79 *$ & .20 & 9.03 \\
\hline $\begin{array}{l}\text { I recommend to buy the } \\
\text { Xbox } 360 \text { video game } \\
\text { console }\end{array}$ & <-------- & $\begin{array}{l}\text { Video game } \\
\text { genres }\end{array}$ & .535 & .39 & 1.37 \\
\hline $\begin{array}{l}\text { I recommend to buy the } \\
\text { PlayStation } 3 \text { video game } \\
\text { console }\end{array}$ & <-------- & $\begin{array}{l}\text { Video game } \\
\text { genres }\end{array}$ & $1.52 *$ & .23 & 6.70 \\
\hline
\end{tabular}

$* \mathrm{p}<.001$ 


\section{Discussion}

This study sought to explore the antecedents of aggregate seventh generation video game consoles brand personality perceptions and its impact on aggregate seventh generation video game console brand loyalty. The concepts of brand relationship theory (Fournier 1998) as well as Aaker's brand personality scale (1997) are reinforced by the results of this study, as video game genres were found to impact the aggregate seventh generation video game console brand personality perceptions, which in turn impacted aggregate seventh generation video game console brand loyalty. It is likely that consumers aggregate seventh generation video game consoles brand personality perceptions by playing video game genres, which in turn allowed them to conceptualize a relationship between themselves and the video game console brands. The aggregate seventh generation video game consoles brand personality perceptions positively influenced aggregate seventh generation video game console brand loyalty. This corroborates prior research that suggested that consumer loyalty may be impacted by perceived brand personalities, which is a result of consumer relationships with brands (Aaker, 1992; Biel, 1992; Doyle, 1990; Eglesz, Feteke, Kiss, \& Izzo, 2005; Fournier, 1998; Freeman, 2004; Harris \& Flemming, 2005; Kim, Magnini, \& Singal, 2011; Kumar, Luthra, \& Datta, 2006; Kwak, McDaniel, \& Kim, 2012). The manner in which consumers perceive aggregate seventh generation video game console brand personalities may affect the duration of their relationships with video game consoles, as well as whether or not they decide to continue to use the same video game console brand.

Gender did not fit into the model, and also did not to impact aggregate brand personality perceptions of the seventh generation of video game consoles. It is possible that since the gender ratio of video game playing audiences is close to being even according to ESA (2012), it is likely that video game player gender is less relevant in determining aggregate seventh generation video game console brand personality perceptions. Network externality had a positive, though not statistically significant, influence upon aggregate seventh generation video game console brand personality perceptions. These interactions may not influence how consumers cultivate individual perceptions of aggregate seventh generation video game console brand personalities. 
Video game genres wielded a statistically significant influence over how consumers cultivated aggregate seventh generation video game console brand personality perceptions. Additionally, video game genres possessed a positive influence over whether or not consumers played video games with others, purchased video game consoles, as well as how their aggregate seventh generation video game console brand loyalty is shaped, though excluding the Xbox 360 on both accounts. Video game genres may serve as a way in which to broach interest in a video game console among video game players as well as maintain a relationship with it. If video game players play video game genres that they enjoy, this will engender positive feelings and video game console brand loyalty. Video game genres appear to inspire video game players to play video games with each other and consider purchasing video game consoles. It is possible that, as a video game player plays a video game with friends, she is also exposed to a particular video game genre on the video game console. Hence, it becomes more desirable to cultivate the relationship between herself and the video game console. This may propel a video game player to purchase a video game console. Since video game players' brand loyalty toward the Xbox 360 was not be influenced by video game genres, it may be due to the Xbox 360's offering of alternative media and entertainment options and services through the console (Schiesel, 2012). As a result, consumers may derive brand loyalty for the Xbox 360 in other ways, since its brand loyalty is less dependent upon video game genres and video game play than the other seventh generation video game consoles.

\section{Limitations}

A convenience sample of undergraduate students at a southeastern university in the United States was used in this study and cannot be generalized to the general public. The findings of this study are limited to the seventh generation of video game consoles. Moreover, the constructed mediator in the structural equation model was based on a convenience sample, and therefore may not be generalizable.

\section{Future Studies}

Future studies should consider different or alternative approaches in measuring how social video game play may or may not affect perceptions of video game console brand personalities among consumers. Future researchers should investigate how genre affects video game console brand personalities, specifically how video games packaged with video game console sales 
affect initial consumer perceptions of video game console brand personalities. Further investigation is needed into how consumers' exposure to other Sony, Nintendo and Microsoft products may affect their attitudes toward video game consoles and visa-versa. Lastly, more research is needed to understand how brand loyalty may be fostered differently by consumers who are loyal to the Xbox 360.

\section{Conclusion}

This study investigated how gender, network externality and video game genres, mediated by aggregate seventh generation video game console brand personality perceptions, impacted aggregate seventh generation video game console brand loyalty. Aggregate seventh generation video game console brand personality perceptions of the seventh generation of video game consoles were found to impact aggregate seventh generation video game console brand loyalty. Video game genres were found to have tremendous positive impact upon aggregate seventh generation video game console brand personality perceptions and aggregate seventh generation video game console brand loyalty. It is clear that video game genres can inspire video game play, video game console purchases as well as brand loyalty toward seventh generation consoles, but for the Xbox 360. These findings may aid industry practitioners who are eager to create points of differentiation between themselves and other video game console companies. It may behoove industry practitioners to consider emphasizing the type or amount of video game genres on their video game consoles. Earning exclusive rights to a slew of video games in one particular genre may prove to be a formidable point of differentiation against other rival video game console companies. The model put forth in this article is largely exploratory in nature and will need to be tested with every subsequent video game console generation. There may also be user personalities that align with particular video game console brand personalities, thus creating varying levels of self-congruency.

The study contributed to the academic literature stream on video game consumer behavior, particularly referring to the antecedents that impact aggregate seventh generation video game console brand personality perceptions as well as how it impacts aggregate seventh generation video game console brand loyalty. From a brand management perspective, this study provided advancement toward a better understanding of what variables may influence how consumers 
create brand personalities of video game consoles, as well as how this may impact loyalty toward these video game console. 


\section{References}

Aaker, D. (1991). Managing brand equity: Capitalizing on the value of a brand name. New York, NY: Free Press.

Aaker, D. A. (1992). The value of brand equity. The Journal of Business Strategy, 13, 27-32.

Aaker, J. L. (1997). Dimensions of brand personality. The Journal of Marketing Research, 34(3), 347-356.

ABC News. (2005, November 22). Nov. 22, 2005: Xbox 360 hits stores. In ABC News. Retrieved April 16, 2013, from http://abcnews.go.com/Archives/video/nov-222005Xbox-360-hits-stores-11946797

Ahluwalia, Y. (2000). Examination of psychological processes underlying resistance to change. Journal of Consumer Research, 27(2), 217-232.

Anderson, J. C., \& Gerbing, D. W. (1988). Structural equation modeling in practice: A review and recommended two-step approach. Psychological Bulletin, 103(3), 411423.

Anisimova, T. A. (2007). The effects of corporate brand attributes on attitudinal and behavioral consumer loyalty. The Journal of Consumer Marketing, 24(7), 1-11.

Benedetti, W. (2012, September 13). Nintendo's Wii U will arrive Nov. 18 and cost you \$300, \$350. In NBC News. Retrieved on April 16, 2013 from http://www.nbcnews.com/technology/ingame/nintendos-wii-u-will-arrive-nov-18costyou-300-996023

Biel, A. L. (1992). How brand image drives brand equity. Journal of Advertising Research, 32(6), RC6-RC12.

Bloemer, J., \& Hans, K. (1995). The complex relationship between consumer satisfaction and brand loyalty. Journal of Economic Psychology, 16(2), 311-329.

Brakus, J. J., Schmitt, B. H., \& Zarantonello, L. (2009). Brand experience: What is it? How is it measured? Does it affect loyalty? Journal of Marketing 73(3), 52-68.

Chan-Olmsted, S., \& Cha, J. (2007). Brand television news in a multichannel environment: An exploratory study of network news brand personality. The International Journal on Media Management, 9(4), 135-150.

Chaudhuri, A., \& Holbrook, M. (2001). The chain of effects from brand trust and brand affect to brand performance: The role of brand loyalty. The Journal of Marketing, 65(2), 8193. 
Chen, B. X., \& Streitfeld, D. (2013, February 20). With PlayStation 4, Sony aims for return to glory. The New York Times. Retrieved on April 16, 2013 from http://www.nytimes.com/2013/02/21/technology/sony-unveils-playstation-4aimingfor-return-to-glory.html?_r=0

Costello, A., \& Osborne, J. (2005). Practical assessment, research \& evaluation. The Journal of Consumer Marketing, 10(7), 1-9.

Cruea, M., \& Park, S. (2012). Gender disparity in video game usage: A third-person perception-based explanation. Media Psychology, 15(1), 44-67.

Deleon, N. (2010, July 21). Microsoft allays the fears of its hardcore Xbox 360 gamers, says Kinect will eventually be for them too. In Tech Crunch. Retrieved on March 27, 2013 from http://techcrunch.com/2010/07/21/microsoft-allays-the-fears-of-itshardcoreXbox-360-gamers-says-kinect-will-eventually-be-for-them-too/

Delgado-Ballester, E., Munuera-Aleman, J. L., \& Yague-Guillen, M. J. (2003). Development and validation of a brand trust scale. International Journal of Market Research, 45(1), $35-53$.

Dick, A., \& Basu, K. (1994). Customer loyalty: Toward an integrated conceptual framework. Journal of the Academy of Marketing Science, 22(2), 99-113.

Digital Trends Staff. (2012, May 18). DT debate: Did the Wii's casual gaming hurt or help Nintendo? In Digital Trends. Retrieved March 27, 2013, from http://www.digitaltrends.com/gaming/dt-debate-wii-casual-gaming-hurt-nintendo/

Doyle, P. (1990). Building successful brands: The strategic options. The Journal of Consumer Marketing, 7, 5-20.

Eglesz, D., Feteke, I., Kiss, O., \& Izzo, L. (2005). Computer games are fun? On professional games and players' motivations. Educational Media International, 42(2), 117-124.

Elliot, L., Golub, A., Ream, G., \& Dunlap, E. (2012). Video game genre as a predictor of problem use. Cyberpsychology, Behavior, and Social Networking, 15(3), 155-161.

Entertainment Software Association. (2012a). Game player data. In Entertainment Software Association. Retrieved on March 28, 2013 from http://www.theesa.com/facts/gameplayer.asp

Entertainment Software Association. (2012b). Industry facts. In Entertainment Software Association. Retrieved on April 23, 2013 from http://www.theesa.com/facts/ 
Entertainment Software Association (2013). The transformation of the video game industry. (2013). In Entertainment Software Association. Retrieved on March 28, 2013 from http://www.theesa.com/games-improving-what-matters/transformation.asp

Fournier, S. (1998). Consumers and their brands: Developing relationship theory in consumer research. Journal of Consumer Research, 24(4), 343-373.

Freeman, D. (2004). Creating emotion in games: The craft and art of emotioneering. ACM Computers in Entertainment, 2(3), 1-11.

GameSpy Staff. (2009, March 2). The top 25 Xbox 360 games of all time (so far!). In Gamespy (powered by IGN). Retrieved on April 27, 2013 from http://Xbox360.gamespy.com/articles/958/958192p1.html

Goldsmith, R., \& Goldsmith, E. (2012). Brand personality and brand engagement. American Journal of Management, 12(1), 11-20.

Govers, P., \& Schoormans, J. (2005). Product personality and its influence on consumer preference. The Journal of Consumer Marketing, 22(4), 189-197.

Greenberg, B. S., Sherry, J., Lachlan, K., Lucas, K., \& Holmstrom, A. (2008). Orientations to video games among gender and age groups. Simulation Gaming, 41(2), 238-259.

Guest, L. (1964). Brand loyalty revisited: A twenty-year report. Journal of Applied Psychology, 48, 93-97.

Katz, M. L., \& Shapiro, C. (1985). Network externalities, competition, and compatibility. The American Economic Review, 75(3), 424-440.

Keller, K. L. (1993). Conceptualizing, measuring, and managing customer-based brand equity. The Journal of Marketing, 57(1), 1-22.

Kim, J., Baek, T., \& Martin, H. J. (2010). Dimensions of news media brand personality. Journalism \& Mass Communication Quarterly, 87(1), 117-134.

Kim, D., Magnini, V. P., \& Singal, M. (2011). The effects of customers' perceptions of brand personality in casual theme restaurants. International Journal of Hospitality Management, 30(2), 448-458.

Kumar, R., Luthra, A., \& Datta, G. (2006). Linkages between brand personality and brand loyalty: A qualitative study in an emerging market in the Indian context. South Asian Journal of Management, 13(2), 11-35. 
Kwak, D., McDaniel, S., \& Kim, K. (2012). Revisiting the satisfaction-loyalty relationship in the sport video game context: The mediating role of consumer expertise. Journal of Sport Management, 26, 81-91.

Hamlen, K. R. (2010). Re-examining gender differences in video game play: Time spent and feelings of success. Journal of Educational Computing Research, 43(3), 293-308.

Hu, L., \& Bentler, P. (1999). Cutoff criteria for fit indexes in covariance structure analysis: Conventional criteria versus new alternatives. Structural Equation Modeling - A Multidisciplinary Journal, 6(1), 1-55.

Jain, S., \& Maheswaran, D. (2000). Motivated reasoning: A depth-of-processing perspective. Journal of Consumer Research, 26(4), 358-371.

Jain, S. (2003). Preference consistency and preference strength: Processing and judgmental issues. Journal of Applied Social Psychology, 33(5), 1088-1109.

Levy, S. J. (1999). Brands, consumers, symbols and research. Thousand Oaks, CA: Sage.

Lin, L. (2010). The relationship of consumer personality trait, brand personality and brand loyalty: An empirical study of toys and video game buyers. Journal of Product \& Brand Management, 19(1), 4-17.

Lucas, K., \& Sherry, J. L. (2004). Sex differences in video game play: A communicationbased explanation. Communication Research, 31(5), 499-523.

Morris, C. (2001, November 15). Microsoft Launches Xbox. In CNN Money. Retrieved on April 23, 2013 from http://money.cnn.com/2001/11/15/technology/Xbox/

Morris, C. (2006, November 15). Nintendo Wii: Funny name, fun system: Nintendo gambles with its new video game system -- and the rewards could be big. In CNN Money. Retrieved on March 27, 2013 from http://money.cnn.com/2006/11/15/commentary/wii_review/

Nair, R., \& Mohandas, R. (2012). Impact of gender on brand perception: International and national apparel brands. SIES Journal of Management,8(1) 83-91.

Nielsen. (2009, February 17). Every gaming system has its fans, but women like Wii. In Nielsen. Retrieved on November 29, 2013 from http://www.nielsen.com/us/en/newswire/2009/every-gaming-system-has-its-fansbutwomen-like-wii.html

Nielsen. (2012, March 9). Trend in U.S. video gaming - The rise of cross-platform. In Nielsen. Retrieved on April 26, 2013 from 
http://www.nielsen.com/us/en/newswire/2012/the-latest-trends-in-usvideogaming.html

Oliver, R. (1999). Whence consumer loyalty? Journal of Marketing, 63, 33-44.

Palomba, A. (2014). Brand personalities of video game consoles. Presented at 2014 AEJMC. Montreal, Canada.

Phan, M. H., Jardina, J. R., Hoyle, S., \& Chaparro, B. S. (2012). Examining the role of gender in video game usage, preference, and behavior. Proceedings of the Human Factors and Ergonomics Society 56th Annual Meeting, 56(1), 1496-1500.

Raju, S., Rao, Unnava, H., \& Montgomery, N. (2009). The moderating effect of brand commitment on the evaluation of competitive brands. Journal of Advertising, 38(2), 21-35.

Schiesel, S. (2006, November 20). A weekend full of quality time with PlayStation 3. The New York Times. Retrieved on March 27, 2013 from http://www.nytimes.com/2006/11/20/arts/20game.html?_r=0

Schiesel, S. (2012, June 4). Microsoft to expand offerings on Xbox Live. The New York Times. Retrieved on December 9, 2013 from http://artsbeat.blogs.nytimes.com/2012/06/04/ microsoft-to-expand-offerings-onXbox-live/?_r=0

Sherry, J. L., \& Lucas, K. (2003, May). Video game uses and gratifications as predictors of use and game preference. Paper presented at the annual conference of the International Communication Association, San Diego, CA.

Smith, C. (2012, November 30). 'Xbox 720' release slated for holiday 2013: Bloomberg news. In The Huffington Post. Retrieved on April 16, 2013 from http://www.nytimes.com/2013/02/21/technology/sony-unveils-playstation-4aimingfor-return-to-glory.html?_r=0

Snow, B. (2012, November 9). Why console gaming is dying. In $C N N$. Retrieved on April 27, 2013 from http://www.cnn.com/2012/11/09/tech/gaming-gadgets/consolegamingdead

Stone, G., \& Stone, D. (1990). Lurking in the literature: Another look at media use habits. Mass Communication Review, 17, 25-33.

Sung, Y., \& Tinkham, S. F. (2005). Brand personality structures in the United States and Korea: common and culture-specific factors. Journal of Consumer Psychology, 15(4), 334-350. 
Thornham, H. (2008). Narratives of the videogame: Gender, gaming and gameplay. (Unpublished doctoral dissertation). University of Ulster, United Kingdom.

Totilo, S. (2012, August 17). Back to his old stomping ground: New Super Mario Bros. 2 for the Nintendo 3DS. The New York Times. Retrieved April 27, 2013, from http://www.nytimes.com/2012/08/18/arts/video-games/new-super-mario-bros-2forthe-nintendo-3ds.html

Tsai, S. (2011). Fostering international brand loyalty through committed and attached relationships. International Business Review, 20(5), 521-534.

VGChartz. (2013f). Game Database: Platform: PS. In VGChartz. Retrieved on April 22, 2013 from http://www.vgchartz.com/gamedb/?name=\&publisher=\&platform=PS\& genre $=\& \min S$ ales $=0 \&$ results $=200$

VGChartz. (2013g). Game Database: Platform: PS2. In VGChartz. Retrieved on April 22, 2013 from http://www.vgchartz.com/gamedb/?name=\&publisher=\&platform=PS2\& genre $=\& \min$ Sales $=0 \&$ results $=200$

VGChartz. (2013a). Game Database: Platform: PS3. In VGChartz. Retrieved on March 28, 2013 from http://www.vgchartz.com/gamedb/?name=\&publisher=\&platform=PS3\& genre $=\& \min$ Sales $=0 \&$ results $=200$

VGChartz. (2013b). Game Database: Platform: Wii U. In VGChartz. Retrieved on March 27, 2013 from http://www.vgchartz.com/gamedb/?name=\&publisher=\&platform=WiiU\& genre $=\&$ mi nSales $=0 \&$ results $=200$

VGChartz. (2013c). Game Database: Platform: Xbox360. In VGChartz Retrieved on March 27, 2013 from http://www.vgchartz.com/gamedb/?name=\&publisher=\&platform= $\mathrm{X} 360$ \& genre $=\& \mathrm{mi}$ nSales $=0 \&$ results $=200$

VGChartz. (2013d). North America Hardware Totals. In VGChartz. Retrieved on December 7, 2013 from http://www.vgchartz.com/analysis/platform_totals/

Williams, D., Yee, N., \& Caplan, S. E. (2008). Who plays, how much, and why? Debunking the stereotypical gamer profile. Journal of Computer-Mediated Communication, 13, 993-1018.

Wingfield, N. (2012, November 26). Nintendo's Wii U starts strong. The New York Times. Retrieved on December 8, 2013 from http://bits.blogs.nytimes.com/2012/11/26/ nintendos-wii-u-starts-strong/?_r=0 
Yoon, Y., \& Uysal, M. (2005). An examination of the effects of motivation and satisfaction on destination loyalty: A structural model. Tourism Management, 26(1). 